\title{
Monitoring of Rock Mass Behavior at the Closest Proximity to Hypocenters in South African Gold Mines
}

\author{
by Hiroshi Ogasawara and the Research Group for Semi-controlled Earthquake- \\ Generation Experiments in South African Deep Gold Mines
}

doi:10.2204/iodp.sd.s01.11.2007

To bridge the scale gap between a laboratory scale and a large earthquake scale, we need experiences in an intermediate scale at the smallest distance from the hypocenters (Fig. 1). However, the closest monitoring is not always easy, and the San Andreas Fault Observatory at Depth (SAFOD) is an exceptional opportunity to obtain experiences from natural small earthquakes (Hickman et al., 2004). Tremors in deep mines resemble natural small earthquakes, being also good to take a close look at the hypocenters (Spottiswoode and McGarr, 1975). Recently, modern monitoring is carried out with wider dynamic range and frequency band (Mendecki, 1997). The Research Group for the Semi-controlled Earthquake-Generation Experiments in South African Deep Gold Mines (SeeSA) have been co-operating with ISS International Ltd. and South African gold mines to study rock mass behavior (Iio, 1995; Iio and Fukao, 1992; Ishii and the Research Group for Semi-Controlled Earthquake Generation Experiment at South African Gold Mines, 1996; Nicolaysen, 1992; Ogasawara et al., 2001, 2002a, 2005a, 2005b; Sumitomo, 1998). We have deployed eight experimental sites at four gold mines at depths of a few km (Fig. 2; Ogasawara et al., 2002a, 2005a, 2005b), and at one of these we are collaborating with ICDP-DAFSAM/NSF-NELSAM project (PI: Ze'ev Reches).

In 1996, at the Western Deep Levels South Mine (currently Mponeng mine; Fig. 2), we deployed an array of nine triaxial accelerometers within $100 \mathrm{~m}$ of potential hypocenters of $\mathrm{M}>2$ earthquakes, successfully delineating the finest details of small earthquakes. The relationship between seismic moment and corner frequency was the same as that for

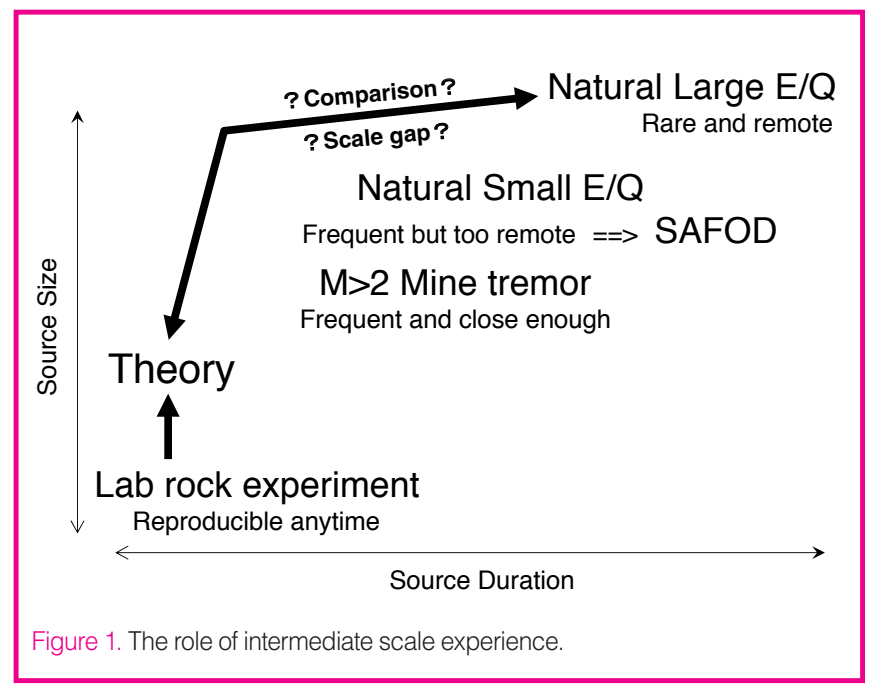

medium or large natural earthquakes (Ogasawara et al., $2002 b)$. The source processes of some M 1 or smaller earthquakes were as complicated as large, natural earthquakes (Yamada et al., 2005).

During 2000-2003 at the Bambanani mine (Figs. 2 and 3), we successfully recorded the rock-mass behavior in the entire life span of M2.4 and M2.5 earthquakes (Mw2.9 and Mw2.0, respectively, in Fig. 4a; Ishii et al., 2000; Ogasawara et al., 2005a; Takeuchi, 2005). We installed an Ishii strainmeter (Ishii et al., 1997) within $100 \mathrm{~m}$ of the seismic sources and recorded the data continuously with resolutions of $25-\mathrm{Hz}$ and 24-bit. The initial significant change was by an $\mathrm{Mw} 0.2$ event in September 2001 within a few tens of meters. The largest event (Mw3.0) within $250 \mathrm{~m}$ of the strainmeter took place in 2002, however, not close enough to cause the largest strain change. The largest strain changes were associated with two M2 events within $100 \mathrm{~m}$ of the strainmeter in 2003 (yellow circles in Fig.3, upper). The strain change was as large as 100 microstrain, corresponding to several MPa. Such a large change is recorded only at the closest distance from the seismic fault. Channel 1 subparallel to the maximum principal stress was contracting until the M2 sequence and then was released by the sequence.

However no accelerating strain preceded the hundreds of co-seismic steps for the catalogued seismic events, even for those of $\sim 100$ microstrain (stress drop $\sim \mathrm{MPa}$ ) (Ogasawara et al., 2005a; Takeuchi, 2005).

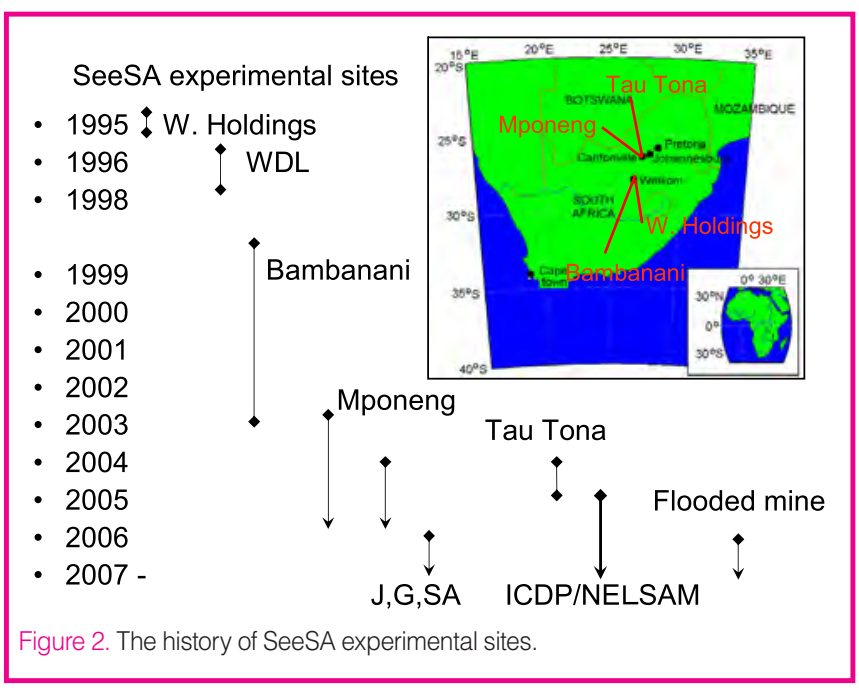




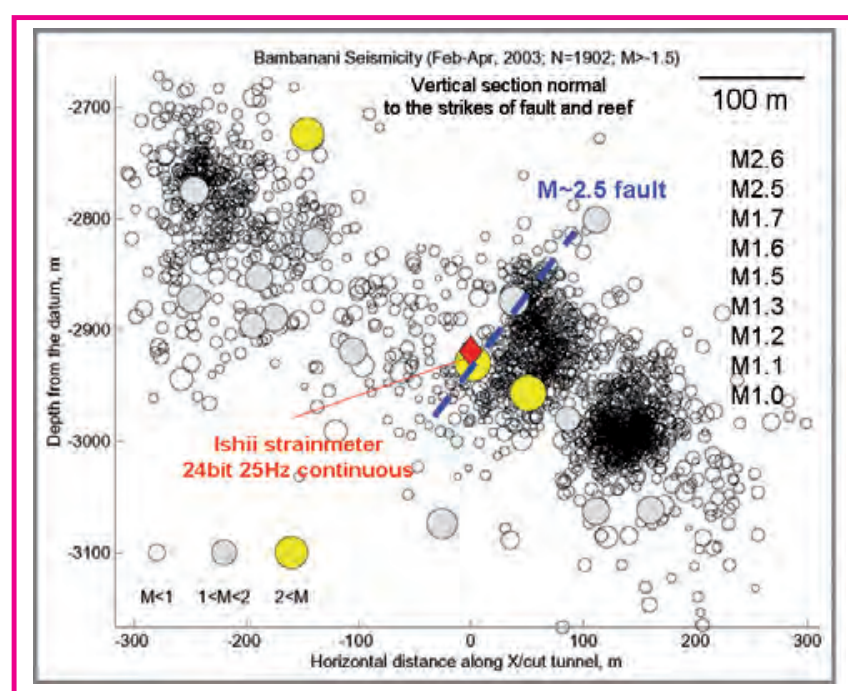

Figure 3. Configuration of an Ishii strainmeter, the M2.5 fault and the seismicity (Feb-Apr 2003) at the site at the Bambanani mine, Welkom.

Thoroughly going through the strain recordings, Yamamoto et al. (2006) found that the Ishii strainmeter picks up seismic events smaller than $\mathrm{M}=-1$ (much more than those catalogued by the mine's seismic network). They also found hundreds of the aftershocks having variable senses of strain steps and postseismic changes. This suggests the strainmeter was located within the aftershock area.

The step response to the catalogued earthquake accompanied overshoot and ringing (Fig. 4b; hereinafter, dynamic

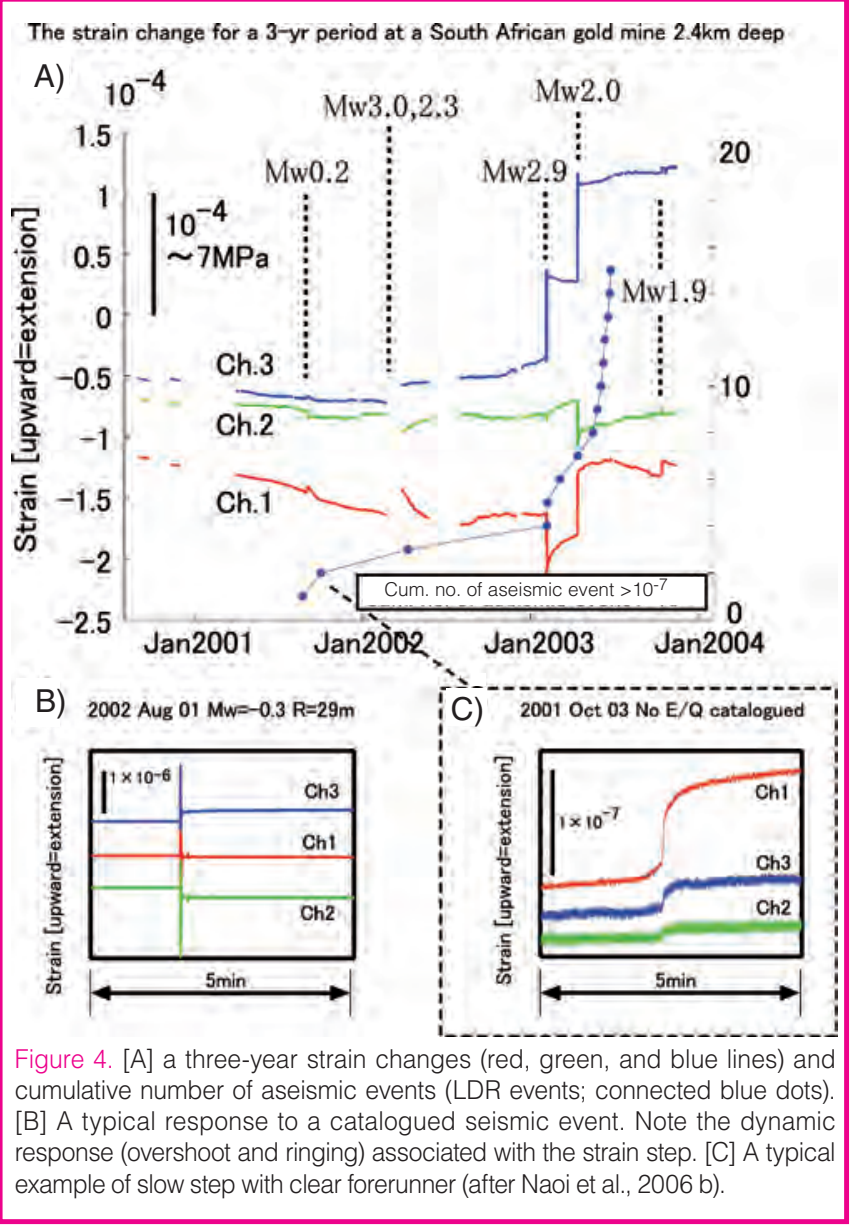

\section{Statistics of strain events $>10^{-7}$}

Out of 70 events $\left(>10^{-7}\right)$

$\{38:$ catalogued $E / Q(M>-0.5)$

32: others

$\left\{\begin{array}{l}\text { 6: Significant Dynamic Response } \\ \text { 11: Not easily categorized } \\ \text { 15: Little Dynamic Response (LDR) }\end{array}\right.$

$\left\{\begin{array}{l}\text { 3: Very slow, } \\ \text { some preceded by forerunner } \\ \text { 12: Others }\end{array}\right.$

Figure 5. The statistics of the strain events (data after Naoi et al., 2006a).

response). However, Naoi et al. (2006a) found that slow strain-steps as small as 0.1 microstrain were also frequently recorded with little dynamic response (LDR). They found that the step durations were variable and significantly longer than normal seismic steps (Fig. 4c; the moments possibly correspond to $\mathrm{M}=-1$ or smaller seismic events). Interestingly, most LDR events took place after the large strain change and few very slow events were preceded by the significant accelerating strain (Figs. 4c and 5).

The entire lifespan of a large natural earthquake includes loading, foreshocks, main rupture, aftershocks, and postseismic deformation. Slow events are also associated. The forerunning, accelerating deformation is not often observed, however.

For $-1<\mathrm{M}<2$ mine tremors, we again observed almost the same set of phenomena. Additionally, we could find the clear forerunners associated only with the small, slow strain event. We were able to see them because we were able to install strainmeters within seismic sources.

Monitoring the smaller subsets of the phenomena (gray area in Fig. 6) could be interesting. To get the time and magnitude range closer to those for $\mathrm{AE}$, we start the strain

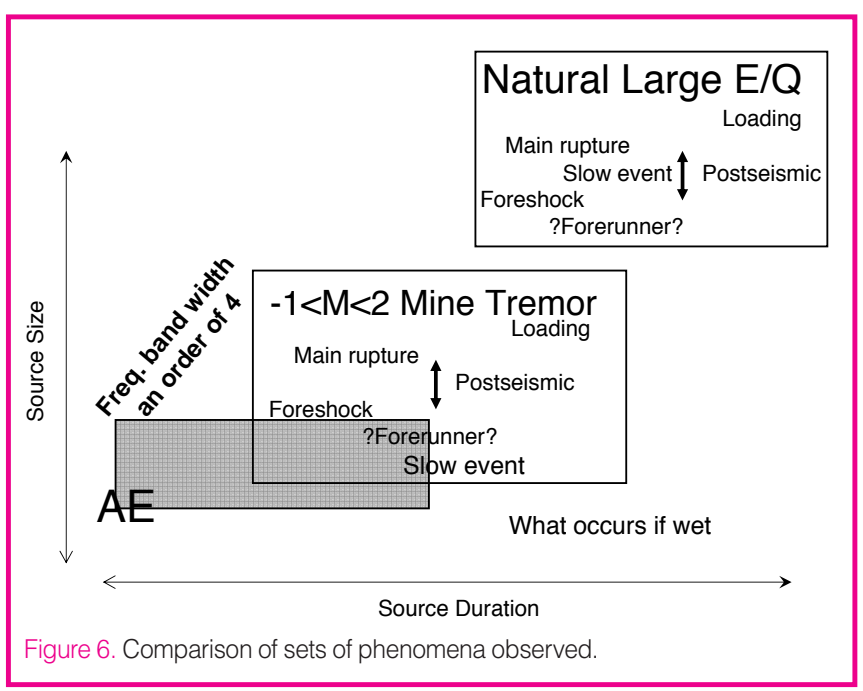




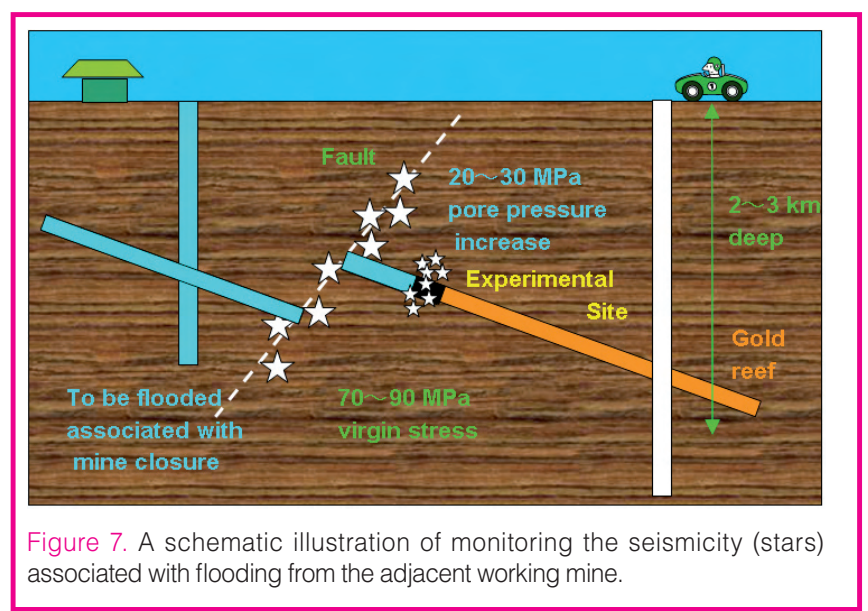

monitoring with much higher sampling rate at new sites. One of these is carried out collaterally with Nakatani et al., (2006) who attempted to monitor the wide dynamic/ frequency range of fracturing process from $\mathrm{AE}$ (up to $200 \mathrm{kHz}$ ) to seismic events at a potential seismic fault.

At the previous experimental sites, the rock mass was not saturated with water. We also have to learn what behavior can be seen under wet conditions, and along these lines, the flooded South African gold mines are very unique cases to provide us with good experimental sites. We can investigate 1) the effects of flooding and the corresponding rising water levels on the stability of faults and other geological features, 2) the effects of seismicity on inter-mine water plugs and mine barriers pillars, and 3) seismic damage risks to neighboring mines in areas in which mines are mature.

These investigations are very crucial because the behavior of highly stressed rock mass during flooding is presumably analogous to that during natural earthquake swarms or stable or unstable slip at natural great earthquakehypocenters under water-saturated conditions. We cannot access inside the earthquake swarm in Japan, but we can do it in South Africa.

\section{References}

Hickman, S., Zoback, M., and Ellsworth, W., 2004. Introduction to special section: Preparing for the San Andreas Fault Observatory at Depth. Geophys. Res. Lett., 31:L12S01, doi:10.1029/2004GL020688.

Iio, Y., 1995. Earthquake prediction in South African gold mines. Iwanami Science 65:279-281 (in Japanese).

Iio, Y. and Fukao, Y., 1992. Call for joining international experiment in South African gold mines. Newsletter, Seismol. Soc. Jpn., 3(6):8-9 (in Japanese).

Ishii, H. and the Research Group for Semi-controlled Earthquake Generation Experiments at South African Gold Mines, 1996. Semi-controlled experiment in a gold mine in South Africa (5) - strain observation by borehole strain meters. Abstracts. 1996 Japan Earth Planet. Sci. Joint Meeting: A58 (in Japanese).

Ishii, H., Nakao, S., Ogasawara, H., and the Research Group for Semicontrolled Earthquake Generation Experiment at South
African Gold Mine, 2000. Continuous monitoring of strain by $25 \mathrm{~Hz} 24$ bit sampling using Ishii's borehole strainmeter on a hypocentral fault where an $\mathrm{M}>3$ event is expected semi-controlled experiment in a gold mine in South Africa (25). Abstracts. Seism. Soc. Jpn., 2:A58 (in Japanese).

Ishii, H., Yamauchi, T., and Kusumoto, F., 1997. Development of high sensitivity bore hole strain meters and application for rock mechanics and earthquake prediction study. Rock Stress. Rotterdam (Balkema), 253-258.

Mendecki, A.J. (Ed.), 1997. Seismic Monitoring in Mines. London (Chapman and Hall), 262 pages.

Nakatani, M., Carstens, R., Stanchits, S., Philipp, J., van Aswegen, G., Ide, S., Miyake, H., Yabe, Y., Ogasawara, H., Dresen, G., Manthei, G., Ward, T., and Sumitomo Norihiko International Research Group for Semi-controlled Earthquake Generation Experiment at South African Gold Mine, 2006. An ultraaccessible fault of an impending earthquake at a $3.5 \mathrm{~km}$ depth in a South African gold mine. Abstract, the Japan Geoscience Union Meeting 2006, S109-P004.

Naoi, M., Ogasawara, H., Takeuchi, J., Yamamoto, A., Shimoda, N., Morishita, K., Ishii, H., Nakao, S., van Aswegen, G., Mendecki, A.J., Lenegan, P., Ebrahim-Trolloope, R., and Iio, Y., 2006a. Small slow-strain steps and their forerunners observed in gold mine in South Africa. Geophys. Res. Lett., 33:L12304, doi: 10.1029/2006GL026507.

Naoi, M. Ogasawara, H., Takeuchi, J., Shimoda, N., Morishita, K., Ishii, H., Nakao, S., Mendecki, A.J., van Aswegen, G., Ebrahim-Trollope, R. and Iio, Y., 2006b. Newsletter, Seismol. Soc. Jpn., 18(1), cover page (in Japanese).

Nicolaysen, L.O., 1992. International semi-controlled experiment on seismic events: a review of the background and proposal. Newsletter, Seismol. Soc. Jpn,. 3(6):9-27.

Ogasawara, H. Miwa, T., and The Research Group for Semi-controlled Experiment in South African Gold Mines, 2002b. Microearthquake scaling relationship using near-source, redundant, wide-dynamic-range accelerograms in a South African deep gold mine. In Ogasawara, H., et al. (Eds.), Seismogenic Process Monitoring, Rotterdam (Balkema), 151164.

Ogasawara, H. and The Research Group for Semi-controlled Experiments in South African Gold Mines, 2002a. Semicontrolled earthquake generation experiment in South African gold mine. A review of the semi-controlled earthquake generation experiment in South African Deep Gold Mines (1992-2001). In Ogasawara, H., et al. (Eds.), Seismogenic Process Monitoring, Rotterdam (Balkema), 119-150.

Ogasawara, H., Sato, S., Nishi, S., Sumitomo, N., Ishii, H., Iio, Y., Nakao, S., Ando, M., Takano, M., Nagai, N., Ohkura, T., Kawakata, H., Satoh, T., Kusunose, K., Cho, A., Mendecki, A., Cichowicz, A., Green, R.W.E., and Kataka, M.O., 2001. Semi-controlled seismogenic experiments in South African deep gold mines. Proc. 5th Internat. Symp. Rockburst and Seismicity Mines, 293-300.

Ogasawara, H., Takeuchi, J., Shimoda, N., Ishii, H., Nakao, S., van Aswegen, G., Mendecki, A.J., Cichowicz, A., EbrahimTrollope, R., Kawakata, H., Iio, Y., Ohkura, T., Ando, M., and the Research Group for Semi-controlled EarthquakeGeneration Experiments in South African deep gold mines, 
2005a. High-resolution strain monitoring during $\mathbf{M} \sim 2$ events in a South African deep gold mine in close proximity to hypocentres. Proc. 6th Internat. Symp. Rockburst and Seismicity in Mines, 385-391.

Ogasawara, H., Takeuchi, J., Shiimoda, N., Nakatani, M., Kato, A., Iio,Y., Kawakata, H., Yamada, T., Yamauchi, T., Ishii, H., Satoh, T., Kusunose, K., Otsuki, K., Kita, S., Nakao, S., Ward, A.K, McGill, R., Murphy, S.K., Mendecki, A.J., van Aswegen, G., and the Research Group for Semi-controlled Earthquake Generation Experiments in South African Deep Gold Mines, 2005b. Multidisciplinary Monitoring of the Entire Life Span of an Earthquake and its Practical Strategy in South African Gold Mines, Proc. 6 ${ }^{\text {th }}$ Internat. Symp. Rockburst and Seismicity in Mines, 393-398.

Spottiswoode, S.M. and McGarr, A., 1975. Source parameters of tremors in a deep-level gold mine. Bull. Seismol. Soc. Amer., 65:93-112.

Sumitomo, N., 1998. International joint research: semi-controlled earthquake generation experiment. Chikyu Monthly, 229:391-394 (in Japanese).

Takeuchi, J., 2005. A study of strain changes associated with earthquakes observed within $100 \mathrm{~m}$ in Bambanani mine, South Africa (in Japanese). M.S. thesis, Ritsumeikan University, Kusatsu.

Yamada, T., Mori, J.J., Ide, S., Kawakata, H., Iio, Y., and Ogasawara , H., 2005. Radiation efficiency and apparent stress of small earthquakes in a South African gold mine, J. Geophys. Res., 110, B01305, doi:10.1029/2004JB003221.

Yamamoto, A., Ogasawara, H., Takeuchi, J., Shimoda, N., Naoi, M., Morishita, K., Ishii, H., Nakao, S., Mendecki, A., van Aswegen, G., Lenegan, P., Ebrahim-Trollope, S., and Sumitomo Norihiko International Research Group for Semicontrolled Earthquake Generation Experiment at South African Gold Mine, 2006. The aftershocks for ultra-microearthquakes seen in $25 \mathrm{~Hz}$ continuous recordings with Ishii strainmeter within M2 source area. Abstract, the Japan Geoscience Union Meeting 2006, S109-P004.

\section{Authors}

Hiroshi Ogasawara, Faculty of Science and Engineering, Ritsumeikan University, 1-1-1 Noji Higashi, Kusatsu, 5258577, Japan, e-mail: ogasawar@se.ritsumei.ac.jp.

The Research Group for Semi-controlled EarthquakeGeneration Experiments in South African Deep Gold Mines, members from Ritsumeikan University, the University of Tokyo, Kyoto University, Nagoya University, Tohoku University, Tono Research Institute of Earthquake Science (TRIES) Japan, National Institute of Advanced Industrial Science and Technology (AIST) Japan, Kanazawa University, ISS International Ltd., Open House Management Solutions Ltd (OHMS), Seismogen CC., Geohydroseis CC., Gesellschaft für Materialprüfung und Geophysik (GMuG), GeoForschungsZentrum Potsdam (GFZ), Western Deep Levels, South mine, Bambanani mine, Tau Tona mine, Buffelsfontein mine, East Rand Proprietary mine. 